\title{
CSF and Blood Levels of GFAP in Alexander Disease
}

Paige L. Jany, ${ }^{1}$ Guillermo E. Agosta, ${ }^{2}$ William S. Benko, ${ }^{3}$ Jens C. Eickhoff, ${ }^{4}$ Stephanie R. Keller, ${ }^{5}$ Wolfgang Köehler, ${ }^{6}$ (D) David Koeller, ${ }^{7,8}$ Soe Mar, ${ }^{9}$ Sakkubai Naidu, ${ }^{10}$ Jayne Marie Ness, ${ }^{11}$ (DDavide Pareyson, ${ }^{12}$ Deborah L. Renaud, ${ }^{13}$ Ettore Salsano, ${ }^{12}$ Raphael Schiffmann, ${ }^{3}$ Julie Simon, ${ }^{14}$ Adeline Vanderver, ${ }^{15}$ Florian Eichler, ${ }^{16}$ Marjo S. van der Knaap, ${ }^{17}$ and ${ }^{(D)}$ Albee Messing ${ }^{1}$

\section{DOI:http://dx.doi.org/10.1523/ENEURO.0080-15.2015}

${ }^{1}$ Waisman Center and Department of Comparative Biosciences, University of Wisconsin-Madison, Madison, Wisconsin 53705, ${ }^{2}$ Department of Child Neurology, Hospital Italiano School of Medicine, C1181ACH Buenos Aires, Argentina, ${ }^{3}$ Developmental and Metabolic Neurology Branch, National Institute of Neurological Disorders and Stroke, National Institutes of Health, Bethesda, Maryland 20814, ${ }^{4}$ Department of Biostatistics and Medical Informatics, University of Wisconsin-Madison, Madison, Wisconsin 53792, ${ }^{5}$ Division of Pediatric Neurology, Emory University, Atlanta, Georgia 30322, ${ }^{6}$ Chefarzt der Klinik für Neurologie und neurologische Intensivmedizin, D-04799 Wermsdorf, Germany, ${ }^{7}$ Department of Molecular \& Medical Genetics, Oregon Health \& Science University, Portland, Oregon 97239, ${ }^{8}$ Department of Pediatrics, Oregon Health \& Science University, Portland, Oregon 97239, ${ }^{9}$ Division of Pediatric Neurology, Washington University St. Louis, St. Louis, Missouri 63110, ${ }^{10}$ Department of Neurology, Johns Hopkins University School of Medicine, Baltimore, Maryland 21205, ${ }^{11}$ Division of Pediatric Neurology, University of AlabamaBirmingham, Birmingham, Alabama 35233, ${ }^{12}$ Department of Clinical Neurosciences, IRCCS Foundation, C. Besta Neurological Institute, 20133 Milan, Italy, ${ }^{13}$ Division of Child and Adolescent Neurology, Departments of Neurology and Pediatrics, Mayo Clinic, Rochester, Minnesota 55901, ${ }^{14}$ Genomics Institute, Multi-Care Health System, Tacoma, Washington 98415, ${ }^{15}$ Children's Research Institute, Children's National Health System, Washington, DC 20010,

${ }^{16}$ Massachusetts General Hospital, Boston, Massachusetts 02114, ${ }^{17}$ Department of Child Neurology, Free University Medical Center, Amsterdam, 1007 MB, The Netherlands

\begin{abstract}
Alexander disease is a rare, progressive, and generally fatal neurological disorder that results from dominant mutations affecting the coding region of GFAP, the gene encoding glial fibrillary acidic protein, the major intermediate filament protein of astrocytes in the CNS. A key step in pathogenesis appears to be the accumulation of GFAP within astrocytes to excessive levels. Studies using mouse models indicate that the severity of the phenotype correlates with the level of expression, and suppression of GFAP expression and/or accumulation is one strategy that is being pursued as a potential treatment. With the goal of identifying biomarkers that indirectly reflect the levels of GFAP in brain parenchyma, we have assayed GFAP levels in two body fluids in humans that are readily accessible as biopsy sites: CSF and blood. We find that GFAP levels are consistently elevated in the CSF of patients with Alexander disease, but only occasionally and modestly elevated in blood. These results provide the foundation for future studies that will explore whether GFAP levels can serve as a convenient means to monitor the progression of disease and the response to treatment.
\end{abstract}

Key words: astrocyte; biomarker; GFAP

\section{Significance Statement}

Glial fibrillary acidic protein (GFAP) is an intermediate filament protein that is predominantly expressed in astrocytes of the CNS. Although typically confined to the cytoplasm, GFAP is released at low levels into the extracellular space, and can appear at measurable levels in CSF and blood. Here we show that the fluid levels of GFAP increase markedly in individuals with Alexander disease, a genetic disorder that results from mutations in GFAP itself, particularly in the CSF. CSF analysis may therefore offer a relatively noninvasive means for indirectly monitoring the levels of GFAP in brain and assessing the efficacy of future experimental treatments that are designed to reduce these levels. 


\section{Introduction}

Alexander disease $(A x D)$ is a progressive and generally fatal neurogenetic disorder, with ages of onset ranging from fetal through late adulthood, resulting from heterozygous dominant mutations in the astrocyte intermediate filament protein glial fibrillary acidic protein (GFAP; Brenner et al., 2001; Messing et al., 2012b). The hallmark feature of the pathology, cytoplasmic aggregates known as Rosenthal fibers within astrocytes, are composed of GFAP (Johnson and Bettica, 1989) along with a number of other proteins such as plectin (Tian et al., 2006), and the small stress proteins $\alpha \mathrm{B}$-crystallin and Hsp27 (Iwaki et al., 1989; Iwaki et al., 1993). Studies in mouse models have led to the conclusion that, unlike most of the other intermediate filament disorders, GFAP mutations act in a gainof-function fashion, and that elevations of total GFAP levels may be a major factor in pathogenesis (Messing et al., 1998; Hagemann et al., 2006; Tanaka et al., 2007). Several strategies are now being pursued as potential treatments for $A x D$, chief among them being pharmacologic approaches for suppressing the expression of GFAP below its toxic threshold or interfering with other downstream effects of GFAP toxicity (Cho et al., 2010; Messing et al., 2010).

How one might assess the efficacy of any potential treatment is a major question. Although AxD is genetically homogeneous, the clinical presentations are quite varied, with age of onset ranging from fetal through late adulthood. The most widely used classification system is based simply on age of onset, and divides patients into early, juvenile, and adult categories (Russo et al., 1976). More recently, two different classification systems have been proposed that are more reflective of lesion location and symptoms (Prust et al., 2011; Yoshida et al., 2011). No consensus clinical scoring system exists for evaluating

Received July 23, 2015; accepted September 2, 2015; First published September 15, 2015.

The authors declare no competing financial interests.

Author Contributions: A.V., F.E., M.S.v.d.K., and A.M. designed research; P.L.J. and A.M. performed research; G.E.A., W.S.B., S.R.K., W.K., D.K., S.M., S.N., J.M.N., D.P., D.L.R., E.S., R.S., J.S., A.V., F.E., and M.S.v.d.K. contributed unpublished reagents/analytic tools; P.L.J., J.C.E., M.S.v.d.K., and A.M. analyzed data; A.M. wrote the paper.

This work was supported by the National Institutes of Health through the Grants NS060120, NS42803, and HD076892 (A.M.); HD003352 (P30 Core Grant to the Waisman Center); UL1TR000427 (Clinical and Translational Science Award to the School of Medicine and Public Health, University of Wisconsin, Madison). Additional support was provided by The Juanma Fund.

Acknowledgments: We thank the many patients and families who donated samples and shared information for this research. We also thank William Rizzo, Charles Williams, and John Zempel for referring patients to our study.

W.S. Benko's present address: Wellspan Pediatric Neurology, York, PA 17402

R. Schiffmann's present address: Institute of Metabolic Disease, Baylor Research Institute, Dallas, TX 75226

Correspondence should be addressed to Albee Messing, Waisman Center and Department of Comparative Biosciences, University of WisconsinMadison, Madison, Wisconsin 53705. E-mail: amessing@wisc.edu.

DOI:http://dx.doi.org/10.1523/ENEURO.0080-15.2015

Copyright (C) 2015 Jany et al.

This is an open-access article distributed under the terms of the Creative Commons Attribution 4.0 International, which permits unrestricted use, distribution and reproduction in any medium provided that the original work is properly attributed. disease severity or monitoring progression, no clear genotype-phenotype relationships have been identified, and no prospective natural history studies have been performed. While existing MRI criteria are highly reliable as diagnostic tools (van der Knaap et al., 2001, 2005,2006), they are not suitable for quantifying disease severity or monitoring disease progression. Estimates of survival are also changing; Li et al. (2005), in an early review of 44 patients, calculated a median survival time from onset of 3.9 years for the early-onset group, while Prust et al. (2011), based on a much larger cohort of 215 patients, found a median 14-year survival time for the type I patients. Given the wide spectrum of clinical presentations and courses for AxD, there is a clear need to identify and evaluate biomarkers that can serve as surrogate indicators of the potential response to therapy.

One potential biomarker is GFAP itself. GFAP, despite being a cytoplasmic protein, is normally present at low levels in CSF and blood, and the levels in these fluids are increased in the context of a wide variety of injuries and diseases of the CNS (Liem and Messing, 2009; Petzold, 2015). Following traumatic brain injury, particularly ones that are acute and focal, serum GFAP levels rise, and serum GFAP level was recently adopted as a key biomarker for the TRACE-TBI study on common data elements (Yue et al., 2013). In one study of three AxD patients, Kyllerman et al. (2005) reported that CSF levels of GFAP were elevated in each one.

GFAP levels could conceivably serve as a biomarker in AxD in two distinct ways. First is the known association of GFAP release with injury or damage, as cited above; and, indeed, the lesions in AxD range from very subtle, without evident leukodystrophy, up to large cavitating lesions with loss of nearly all tissue elements (Messing and Goldman, 2004). Second is the proposed link between toxic accumulation of GFAP and pathogenesis-GFAP elevation is found in both human patient samples and mouse models (Hagemann et al., 2005, 2006; Tang et al., 2008; Walker et al., 2014), with the mice displaying a clear correlation between levels of GFAP expression and severity of phenotype (Messing et al., 1998; Hagemann et al., 2006). To determine whether GFAP levels can serve as a useful biomarker for $\mathrm{AxD}$ requires replication of the $\mathrm{CSF}$ findings from Kyllerman et al. (2005) in a larger cohort of patients, as well as measurement in more conveniently collected biopsy fluids such as blood.

\section{Materials and Methods}

\section{AxD patient samples}

The sole inclusion criterion for participation in this study was genetic confirmation of the diagnosis by sequencing of GFAP. Informed consent for studies of CSF was obtained following protocols approved by the institutional review boards (IRBs) at the University of WisconsinMadison, the Children's National Medical Center, and the Mayo Clinic. Only leftover samples from a previous clinical use were permitted for study. Informed consent for studies of blood was obtained following protocols approved by IRBs at the University of Wisconsin-Madison, Children's National Medical Center, Massachusetts General 
Table 1: Control CSF samples (sorted by age at collection)

\begin{tabular}{lll}
\hline Age (years) & Sex & Reason for LP \\
0.08 & M & Respiratory syncytial virus bronchiolitis \\
0.08 & F & Acute respiratory failure \\
0.12 & M & Acute life-threatening event \\
0.66 & F & Vomiting \\
2.16 & M & Gastrointestinal virus \\
2.25 & M & Lymphoma \\
3.08 & F & DiGeorge syndrome \\
3.75 & M & Acute lymphocytic leukemia/chemotherapy evaluation \\
3.92 & M & Acute lymphocytic leukemia/chemotherapy evaluation \\
4.08 & M & Acute lymphocytic leukemia/chemotherapy evaluation \\
4.33 & M & Acute lymphocytic leukemia/chemotherapy evaluation \\
5.25 & $\mathrm{M}$ & Acute lymphocytic leukemia/chemotherapy evaluation \\
5.33 & $\mathrm{M}$ & Acute lymphocytic leukemia \\
5.75 & $\mathrm{~F}$ & Acute lymphocytic leukemia/chemotherapy evaluation \\
6.92 & $\mathrm{M}$ & Acute lymphocytic leukemia/chemotherapy evaluation \\
9.25 & $\mathrm{~F}$ & Acute lymphocytic leukemia/chemotherapy evaluation \\
9.58 & $\mathrm{M}$ & Ehlers-Danlos syndrome, mental status change \\
12.33 & $\mathrm{~F}$ & Acute lymphocytic leukemia/chemotherapy evaluation \\
14.16 & $\mathrm{~F}$ & Acute lymphocytic leukemia/chemotherapy evaluation \\
14.75 & $\mathrm{~F}$ & Acute lymphocytic leukemia/chemotherapy evaluation \\
15.33 & $\mathrm{M}$ & Idiopathic intracranial hypertension \\
16.66 & $\mathrm{M}$ & Acute lymphocytic leukemia/chemotherapy evaluation \\
17.33 & $\mathrm{M}$ & Acute lymphocytic leukemia/chemotherapy evaluation \\
19 & & Acute lymphocytic leukemia/chemotherapy evaluation \\
& &
\end{tabular}

Deidentified control CSF samples are tabulated indicating sex and the clinical reason for LP. Age at collection is given in years. F, Female; M, male.

Hospital, Washington University in St. Louis, and the Mayo Clinic. Again, consents were obtained either through in-person interview or by telephone, with written confirmation. For samples collected in The Netherlands, Italy, and Germany, the principles outlined in the Declaration of Helsinki were followed.

\section{Control samples}

Controls for CSF studies consisted of 24 deidentified samples collected by lumbar puncture (LP) for various purposes but considered within the range of normal for protein, glucose, and cell counts. The CSF controls were exempted from the requirement for consent. Additional information about the CSF control group (age, sex, and reason for $L P$ ) is given in Table 1. Controls for blood were obtained from apparently healthy adults of both sexes (27 males, 84 females), who were asked to exclude themselves if they had specific conditions (neurologic or psychiatric disorders, head or brain trauma within the past 12 months, type 1 diabetes, inflammatory bowel disease) or were taking specific medications within the past 3 months (clomipramine, amitriptyline, prednisone, dexamethasone, or tamoxifen). The exclusion criteria for plasma control samples were based on a literature review of conditions known or hypothesized to influence GFAP levels in CSF and blood (Liem and Messing, 2009) and a study specifically aimed at identifying pharmacological modifiers of GFAP expression (Cho et al., 2010).

\section{Plasma preparation}

Fresh samples of venous blood were collected into lavender-topped tubes that contained $\mathrm{K}_{2}$-EDTA as an anticoagulant to allow the preparation of plasma. The samples were centrifuged within 60 min of collection at 2500 relative centrifugal force for $15 \mathrm{~min}$ at room temperature, and the supernatant was immediately placed in a polypropylene tube and stored either on dry ice for shipping or in $\mathrm{a}-20^{\circ} \mathrm{C}$ freezer until shipping could be arranged. Upon arrival at the central laboratory, the samples were then thawed, divided into aliquots, and stored at $-80^{\circ} \mathrm{C}$ until further analysis. Three blood samples were collected as serum rather than plasma, and so were considered nonstandard. Statistical analyses were repeated with or without these samples, and the results were the same.

\section{Quantitation of GFAP}

GFAP levels in CSF and blood were quantitated using a sandwich ELISA, as previously described (Jany et al., 2013). The capture antibodies consisted of a cocktail of monoclonal antibodies (SMI-26R, Covance) diluted in PBS (catalog \#BP3994, Fisher). Plates were blocked with $5 \%$ milk in PBS before the addition of samples or standards diluted in PBS with $0.05 \%$ Tween 20 and 1\% BSA (catalog \#A7030, Sigma-Aldrich), with each sample analyzed in triplicate. Antibody incubation steps were performed in 5\% milk-PBS, and washing steps were performed in PBS-Tween 20. Standard curves were generated using bovine GFAP (catalog \#RDI-PR062007, Fitzgerald Industries International), and reaction volumes consisted of $100 \mu \mathrm{l} /$ well. CSF and plasma samples were initially diluted 1:1 with ELISA buffer, though in some cases higher dilutions were necessary to bring the values within the linear range of the assay. GFAP values were expressed as $\mathrm{ng} / \mathrm{L}$. Under these conditions, the lower limit of detection was $11 \mathrm{ng} / \mathrm{L}$, and the biological limit of de- 


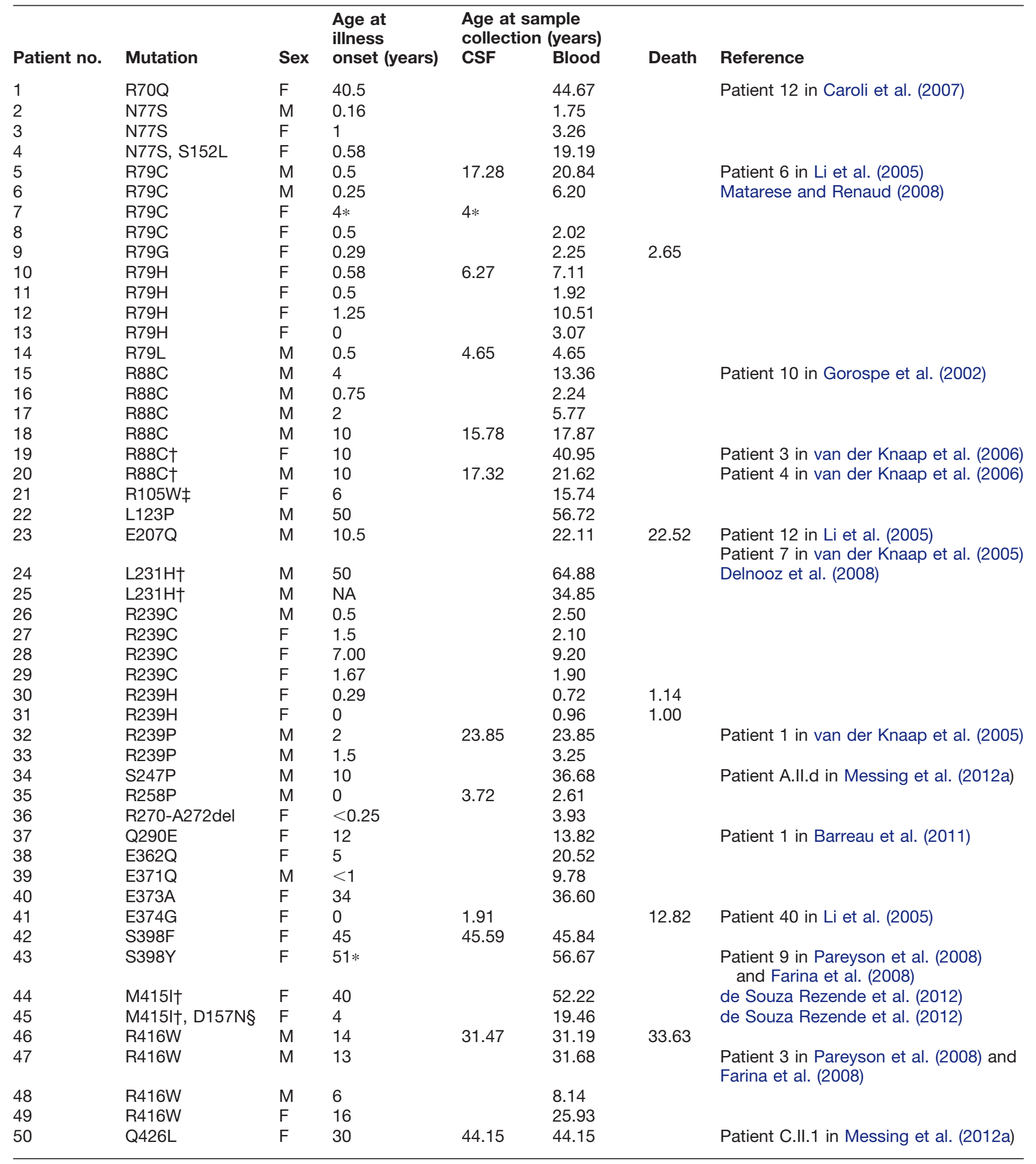

Information regarding each patient who contributed blood and/or CSF samples is shown, including gender, GFAP mutation, age of illness onset, age at sample collection, and age at death (if relevant), and sorted by GFAP mutation. For some patients, the age of illness onset was estimated (*) or the patient was asymptomatic but had a familial history of AxD (NA). All ages are given in years. References to prior publications containing additional clinical details about particular patients are also given, if available. F, Female; M, male.

*Age of onset was estimated.

†Parent-child duos are shown together on consecutive lines (19-20, 24-25, and 44-45).

$\ddagger$ The pathogenicity of the R105 mutation is uncertain.

$\S$ The D157N mutation is considered a benign variant, but its impact in a compound heterozygote is not known. 
tection (BLD; after accounting for the minimum 1:1 dilution with reaction buffer) was $46 \mathrm{ng} / \mathrm{L}$. The intra-assay coefficient of variation, determined using the bovine GFAP standard at $33 \mathrm{ng} / \mathrm{L}$ in 10 sets of triplicate wells, was $13 \%$. The interassay coefficient of variation, determined using pooled CSF samples taken from GFAP $P^{T g}$ mice that overexpress wild-type human GFAP, was $11 \%$. CSF and plasma samples from Gfap-null mice gave readings that were below the BLD in this assay (data not shown), thus validating its specificity. In addition, plasma samples from Gfap-null mice were spiked with known concentrations of purified bovine GFAP to verify that the 1:1 dilutions of plasma used here did not interfere with the sensitivity of the assay (data not shown). All animal procedures were approved by the Animal Care and Use Committee for the Graduate School at the University of Wisconsin-Madison.

\section{Statistics}

GFAP levels obtained from CSF and blood samples were summarized in terms of medians and ranges. To determine a reference range for GFAP levels in blood samples from healthy control samples, we took into account the BLD of the assay ( $46 \mathrm{ng} / \mathrm{L}$ ). Samples yielding values lower than this limit were treated as censored values at $46 \mathrm{ng} / \mathrm{L}$ in the analysis. Due to the presence of censoring, semiparametric quantile regression was conducted (Richardson and Ciampi, 2003). Overall, the quantile regression analysis indicated that there was no age or gender effect on the GFAP values in the control subjects. The nonparametric Wilcoxon rank sum test was used to compare GFAP levels between AxD case patients and control subjects. Analogously, within AxD case patients, the nonparametric Wilcoxon rank test was used to conduct comparisons among subgroups. The Sidak correction was applied when performing multiple comparisons. Ninety-five percent confidence intervals (Cls) for the differences in medians between AxD case patients and control subjects were constructed using the nonparametric bootstrap method. All $p$ values were two sided, and $p<$ 0.5 was used to determine statistical significance. Statistical analyses were conducted using SAS version 9.3 software (SAS Institute).

\section{Results}

\section{Patient population}

Samples were collected from AxD patients with confirmed mutations in GFAP. Those patients for whom leftover clinical CSF samples were available included five females and seven males, ranging in age from 3.7 to 46 years. Those patients from whom blood samples were collected included 26 females and 22 males, ranging in age from $<1$ to 65 years of age. Both blood and CSF samples were available for 10 of these patients. Information for each patient regarding gender, specific mutation, age of first symptom, age at collection of samples, and age at death (if relevant) is provided in Table 2.

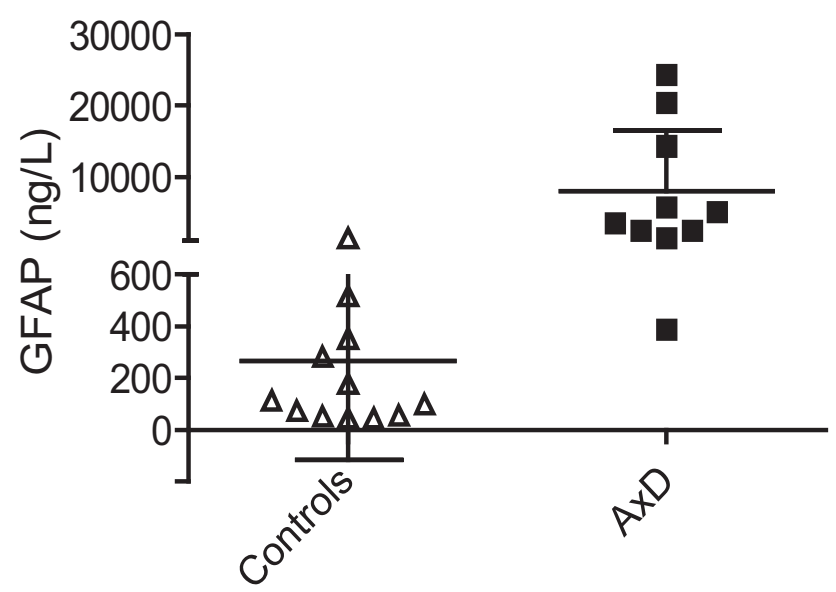

Figure 1. GFAP levels in CSF. GFAP levels (in ng/L) in CSF of AxD patients and control subjects are shown; data are presented as the mean $\pm 1 \mathrm{SD}$ on a split linear scale for the $y$-axis. GFAP levels in samples from AxD patients are significantly elevated compared with those from control subjects. Each data point represents one individual (AxD patients: $n=6$ males, 4 females; control subjects, $n=7$ males, 5 females; Wilcoxon rank sum test, $p<0.001^{\mathrm{a}}$ ).

\section{GFAP levels in CSF}

We established a reference range for CSF controls in our assay using a set of 24 samples, and found the mean GFAP level to be $249 \mathrm{ng} / \mathrm{L}$ (median, $133 \mathrm{ng} / \mathrm{L}$; range, 46-1386 ng/L, with one value falling below the BLD). The highest values in the control group came from one child with lymphoma (site unspecified) and one child with an "acute life-threatening event" (type unspecified). CSF samples were initially available for $10 \mathrm{AxD}$ patients, and in a single assay all of the AxD patient samples were run alongside 12 samples from the control subjects (the control subjects chosen to span the full range as previously identified; Fig. 1). Considered as a group, GFAP levels in the AxD patients were significantly elevated compared with the control subjects (patients: median, $4292 \mathrm{ng} / \mathrm{L}$; range, 387-24272 ng/L; control subjects: median, 103 $\mathrm{ng} / \mathrm{L}$; range, $\left.46-1386 \mathrm{ng} / \mathrm{L} ; p<0.001^{\mathrm{a}}\right)$. Considered as individuals, GFAP levels in 9 of the 10 samples from AxD patients were elevated compared with those from the control population. Because of the paucity of samples, this experiment was replicated once, with similar results. Two additional samples were subsequently received (from patients 35 and 50 ) and analyzed separately, and yielded values of 2721 and $1749 \mathrm{ng} / \mathrm{L}$, respectively. Individual GFAP values for each AxD patient in relation to age, gender, genotype, and duration of illness are shown in Table 3.

\section{GFAP levels in blood}

We established a reference range for plasma controls in our assay using a set of 111 samples obtained from healthy volunteers. Run in their entirety in a single assay, 65 of these samples yielded values in the detectable range, with a median of $61 \mathrm{ng} / \mathrm{L}$ and a $95 \% \mathrm{Cl}$ of $46-861$ $\mathrm{ng} / \mathrm{L}$. This experiment was replicated three times on sub- 
Table 3: GFAP levels in CSF and blood of AxD patients

\begin{tabular}{|c|c|c|c|c|c|c|c|}
\hline \multirow[b]{2}{*}{ Patient no. } & \multirow[b]{2}{*}{ Mutation } & \multirow[b]{2}{*}{ Sex } & \multicolumn{2}{|c|}{$\begin{array}{l}\text { GFAP levels } \\
\text { (nq/L) }\end{array}$} & \multirow{2}{*}{$\begin{array}{l}\text { Age at illness onset } \\
\text { (years) }\end{array}$} & \multicolumn{2}{|c|}{$\begin{array}{l}\text { Duration of illness } \\
\text { (years) }\end{array}$} \\
\hline & & & CSF & Blood & & CSF & Blood \\
\hline 1 & $\mathrm{R} 70 \mathrm{Q}$ & $\mathrm{F}$ & & 64 & 40.5 & & 4.17 \\
\hline 2 & N77S & $\mathrm{M}$ & & 1640 & 0.16 & & 1.59 \\
\hline 3 & N77S & $\mathrm{F}$ & & 802 & 1 & & 2.26 \\
\hline 4 & N77S, S152L & $\mathrm{F}$ & & 480 & 0.58 & & 18.61 \\
\hline 5 & $\mathrm{R} 79 \mathrm{C}$ & $\mathrm{M}$ & 5803 & 256 & 0.5 & 16.78 & 20.34 \\
\hline 6 & $\mathrm{R} 79 \mathrm{C}$ & $\mathrm{M}$ & & 1864 & 0.25 & & 5.95 \\
\hline 7 & $\mathrm{R} 79 \mathrm{C}$ & $\mathrm{F}$ & 3489 & & $3.9 *$ & $0.10 *$ & \\
\hline 8 & $\mathrm{R} 79 \mathrm{C}$ & $\mathrm{F}$ & & 426 & 0.5 & & 1.52 \\
\hline 9 & R79G & $\mathrm{F}$ & & 1201 & 0.29 & & 1.96 \\
\hline 10 & $\mathrm{R} 79 \mathrm{H}$ & $\mathrm{F}$ & 14290 & 1154 & 0.58 & 5.69 & 6.53 \\
\hline 11 & $\mathrm{R} 79 \mathrm{H}$ & $\mathrm{F}$ & & 255 & 0.5 & & 1.42 \\
\hline 12 & $\mathrm{R} 79 \mathrm{H}$ & $\mathrm{F}$ & & 302 & 1.25 & & 9.26 \\
\hline 13 & $\mathrm{R} 79 \mathrm{H}$ & $\mathrm{F}$ & & 572 & 0 & & 3.07 \\
\hline 14 & $\mathrm{R} 79 \mathrm{~L}$ & $\mathrm{M}$ & 20355 & 1925 & 0.5 & 4.15 & 4.15 \\
\hline 15 & $\mathrm{R} 88 \mathrm{C}$ & $\mathrm{M}$ & & 238 & 4 & & 9.36 \\
\hline 16 & $\mathrm{R} 88 \mathrm{C}$ & $\mathrm{M}$ & & 46 & 0.75 & & 1.49 \\
\hline 17 & $\mathrm{R} 88 \mathrm{C}$ & $\mathrm{M}$ & & 329 & 2 & & 3.77 \\
\hline 18 & $\mathrm{R} 88 \mathrm{C}$ & $\mathrm{M}$ & 5095 & 132 & 10 & 5.78 & 7.87 \\
\hline 19 & $\mathrm{R} 88 \mathrm{C}+$ & $\mathrm{F}$ & & 1068 & 10 & & 30.95 \\
\hline 20 & $\mathrm{R} 88 \mathrm{C}$ & $\mathrm{M}$ & 2493 & 122 & 10 & 7.32 & 11.62 \\
\hline 21 & R105W‡ & $\mathrm{F}$ & & 105 & 6 & & 9.74 \\
\hline 22 & L123P & $\mathrm{M}$ & & 219 & 50 & & 6.72 \\
\hline 23 & E207Q & $\mathrm{M}$ & & 751 & 10.5 & & 11.61 \\
\hline 24 & $\mathrm{~L} 231 \mathrm{H} \dagger$ & $\mathrm{M}$ & & 95 & 50 & & 14.88 \\
\hline 25 & $\mathrm{~L} 231 \mathrm{H}$ & $\mathrm{M}$ & & 243 & $\mathrm{~N} / \mathrm{A}$ & & N/A \\
\hline 26 & R239C & $\mathrm{M}$ & & 1007 & 0.5 & & 2.00 \\
\hline 27 & R239C & $\mathrm{F}$ & & 791 & 1.5 & & 0.60 \\
\hline 28 & R239C & $\mathrm{F}$ & & 504 & 7 & & 2.20 \\
\hline 29 & $\mathrm{R} 239 \mathrm{C}$ & $\mathrm{F}$ & & 237 & 1.67 & & 0.23 \\
\hline 30 & $\mathrm{R} 239 \mathrm{H}$ & $\mathrm{F}$ & & 169 & 0.29 & & 0.43 \\
\hline 31 & $\mathrm{R} 239 \mathrm{H}$ & $\mathrm{F}$ & & 711 & 0 & & 0.96 \\
\hline 32 & R239P & $\mathrm{M}$ & 24272 & 713 & 2 & 21.85 & 21.85 \\
\hline 33 & R239P & $\mathrm{M}$ & & 461 & 1.5 & & 1.75 \\
\hline 34 & S247P & $\mathrm{M}$ & & 248 & 10 & & 26.68 \\
\hline 35 & R258P & $\mathrm{M}$ & 2721 & 750 & 0 & & 2.61 \\
\hline 36 & R270-A272del & $\mathrm{F}$ & & 1314 & $0.25 *$ & & $3.68 *$ \\
\hline 37 & Q290E & $\mathrm{F}$ & & 446 & 12 & & 1.82 \\
\hline 38 & E362Q & $\mathrm{F}$ & & 322 & 5 & & 15.52 \\
\hline 39 & E371Q & $\mathrm{M}$ & & 704 & $0.9 *$ & & $8.88 *$ \\
\hline 40 & E373A & $\mathrm{F}$ & & 187 & 34 & & 2.60 \\
\hline 41 & E374G & $\mathrm{F}$ & 387 & & 0 & 1.91 & \\
\hline 42 & S398F & $\mathrm{F}$ & 1402 & 505 & 45 & 0.59 & 0.84 \\
\hline 43 & S398Y & $\mathrm{F}$ & & 112 & $51 *$ & & $5.67 *$ \\
\hline 44 & M415I† & $\mathrm{F}$ & & 46 & 40 & & 12.22 \\
\hline 45 & M415I, D157N§ & $\mathrm{F}$ & & 571 & 4 & & 15.46 \\
\hline 46 & R416W & $\mathrm{M}$ & 2478 & 62 & 14 & 17.47 & 17.19 \\
\hline 47 & R416W & $\mathrm{M}$ & & 545 & 13 & & 18.68 \\
\hline 48 & R416W & $\mathrm{M}$ & & 712 & 6 & & 2.14 \\
\hline 49 & R416W & $\mathrm{F}$ & & 64 & 16 & & 9.93 \\
\hline 50 & Q426L & $\mathrm{F}$ & 1749 & 114 & 30 & 14.15 & 14.15 \\
\hline
\end{tabular}

GFAP concentrations (in ng/L) in CSF and blood of individual AxD patients. Patient 25 was asymptomatic at the time of collection. Duration of illness is defined as the age at sample collection less the age at illness onset, using the values shown in Table 2. Parent-child duos are shown together (19-20, 24-25, and 44-45), as in Table 2. All blood samples are plasma, except for three (9, 16, and 50), which are serum. N/A, not applicable.

*Age at illness onset and duration of illness were estimated.

†Parent-child duos are shown together on consecutive lines (19-20, 24-25, and 44-45).

†The pathogenicity of the R105 mutation is uncertain.

§The D157N mutation is considered a benign variant, but its impact in a compound heterozygote is not known.

sets of control subjects with similar results. Plasma samples from $33 \mathrm{AxD}$ patients were then run in a single assay alongside a subset of samples from 12 control subjects.
The GFAP concentrations in the subset of samples from control subjects compared with the full set of 111 plasma samples from control subjects revealed no significant 


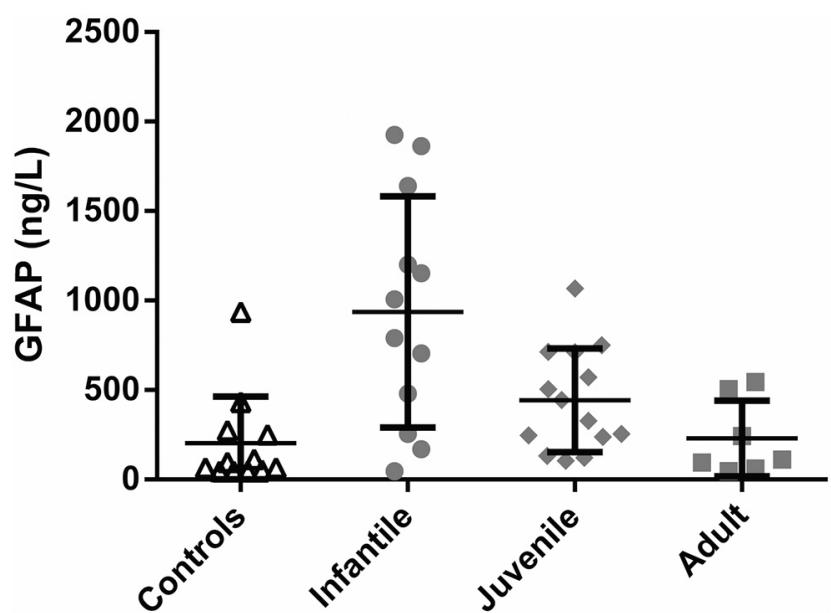

Figure 2. GFAP levels in blood. GFAP levels (in ng/L) in blood of control subjects compared with AxD patients grouped by age of onset (infantile onset, 0-2; juvenile onset, >2-13; adult onset, $>13$ ). Each data point represents one individual. Horizontal bars indicate the mean, and the error bars indicate $\pm 1 \mathrm{SD}$. The infantile group (Wilcoxcon rank sum test, $p=0.002^{\mathrm{b}}$ ) and the juvenile group (Wilcoxon rank sum test, $p=0.025^{\mathrm{C}}$ ) are significantly different than control subjects.

differences (data not shown). Considered as a group, GFAP levels in the AxD patients were significantly elevated in the AxD case patients with infantile $\left(p=0.002^{\mathrm{b}}\right)$ and juvenile $\left(p=0.025^{\circ}\right)$ onsets compared with those in the control subjects (Fig. 2). This assay was repeated three times with similar results. Individual GFAP values for each AxD patient are shown in Table 3.

Subsequent to the experiments described above on the large set of $A x D$ patients, 12 additional samples were received, which were analyzed on three separate occasions (with smaller numbers of control subjects to verify the consistency of the assay). In these latter patients (Tables 2, 3, patients 1, 8, 13, 22, 29, 31, 35-36, 38, 40, 49-50), plasma values ranged from 64 to $1314 \mathrm{ng} / \mathrm{L}$, only patient 36 being higher than the $95 \% \mathrm{Cl}$ established for control subjects.

Both CSF and blood samples were available for $10 \mathrm{AxD}$ patients (though usually collected at different ages; Table 3). For each of these patients, CSF values were significantly higher than the blood values. Although the number of patients was too low for valid statistical analysis, it appears that the blood levels may only exceed the $95 \% \mathrm{Cls}$ of control subjects when the CSF values are above a certain threshold (Fig. 3).

\section{GFAP levels in relation to clinical features}

We analyzed the individual blood and CSF values of GFAP in relation to several aspects of the clinical and genetic histories. Additional clinical information about each AxD patient is given in Table 4. With respect to specific genotype, the 12 CSF samples came from patients with 10 different mutations, and only 2 each for the $\mathrm{R} 79 \mathrm{C}$ and R88C mutations, so no conclusions were possible. For blood samples, five mutations were represented by four to six patients (R79C, R79H, R88C, R239C, and

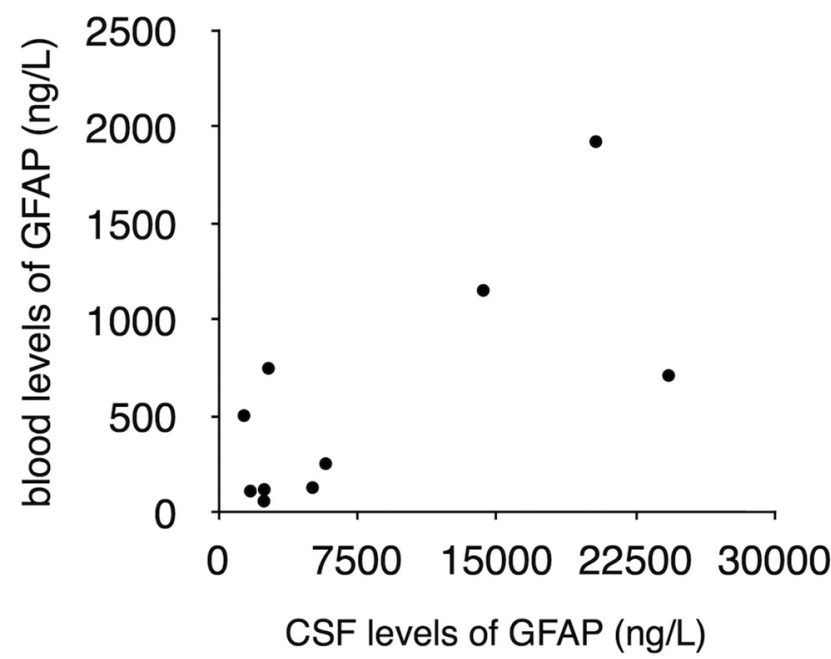

Figure 3. Within-subject comparison of GFAP levels in CSF and blood. GFAP levels in blood are shown as a function of the levels in CSF for the ten patients for whom both types of samples were available. CSF values were consistently higher than blood values. However, as indicated by the ages at collection as given in Table 1, the samples were not contemporaneous. No statistical analysis was performed due to the low number of samples.

R416W), and two samples were available for the one genotype that is generally considered severe $(\mathrm{R} 239 \mathrm{H})$; but the values for GFAP were all highly variable in these groups. Hence, there does not appear to be any direct connection between genotype and the levels of GFAP detected in these assays. In addition, when gender was considered as a variable, there was no significant difference between males and females.

The number of CSF samples was so small that we could not establish any particular connection to age of onset of illness, age at sample collection, or duration of illness (i.e., the difference between the two time points). For blood, the GFAP values were significantly correlated with the age of illness onset and age at sample collection (which is likely linked to the age of onset), but not duration of illness. Four blood samples were from patients sampled within months of their deaths (patients $9,23,30$, and 31), but only one of these had a value that was above the $95 \%$ $\mathrm{Cl}$. If the data are analyzed according to the clinical classification scheme of Russo et al. (1976), which is explicitly tied to age of illness onset, then the GFAP values in patient CSF samples were significantly higher than those in control subjects in all three groups (infantile, juvenile, and adult onset of illness), whereas the values in blood were higher in just the infantile and juvenile groups but not in the adult group. The recent classification scheme of Prust et al. (2011) relies more on clinical features (and hence anatomy) rather than age of illness onset, but still shows a marked age difference. While we did not have sufficient information to allow precise classification according to the criteria of Prust et al. (2011), if one uses an age of $A x D$ onset of $<4$ or $>4$ year as a surrogate for classifying patients as either type I or type II, respectively, then it is clear that the CSF values for AxD patients are significantly elevated in both groups, whereas the 
Table 4: Clinical information on AxD patients

\begin{tabular}{|c|c|c|c|c|c|c|c|c|}
\hline $\begin{array}{l}\text { Patient } \\
\text { no. }\end{array}$ & Mutation & Sex & Onset & First symptom & Highest cognitive & Highest motor & Main deterioration & $\begin{array}{l}\text { Age at loss of } \\
\text { unassisted walking }\end{array}$ \\
\hline 1 & $\mathrm{R} 70 \mathrm{Q}$ & $\mathrm{F}$ & 40.5 & Ataxia & Normal & Walks without support & Gait & No \\
\hline 2 & N77S & M & 0.16 & Frequent arching, seizures & Severe ID & None at all & Severe spasticity, intractable seizures & $\mathrm{N} / \mathrm{A}$ \\
\hline 3 & N77S & $\mathrm{F}$ & 1 & Speech and motor delay & Moderate ID & $\begin{array}{l}\text { Walks without support, } \\
\text { but wide-based gait }\end{array}$ & ND & ND \\
\hline 4 & $\begin{array}{l}\text { N77S, } \\
\quad \text { S152L }\end{array}$ & $\mathrm{F}$ & 0.58 & Seizures & Normal & Walks with support & Motor and language deterioration & $\begin{array}{l}\text { Yet to walk } \\
\text { without support }\end{array}$ \\
\hline 5 & $\mathrm{R} 79 \mathrm{C}$ & M & 0.5 & Motor delay & Mild ID & Walks without support & Spastic tetraparesis, cognitive problems & 14 years \\
\hline 6 & $\mathrm{R} 79 \mathrm{C}$ & M & 0.25 & Macrocephaly, developmental delay & Normal & Walks without support & None & No \\
\hline 7 & $\mathrm{R} 79 \mathrm{C}$ & $\mathrm{F}$ & $4 *$ & ND & ND & ND & ND & ND \\
\hline 8 & $\mathrm{R} 79 \mathrm{C}$ & $\mathrm{F}$ & 0.5 & $\begin{array}{l}\text { Developmental delays in speech, } \\
\text { walking, hypotonia }\end{array}$ & Mild-moderate ID & Standing & Facial droop after concussion & $\begin{array}{l}\text { Yet to walk } \\
\text { without support }\end{array}$ \\
\hline 9 & R79G & $\mathrm{F}$ & 0.29 & Seizures & Severe ID & Sitting without support & Loss of sitting & $\begin{array}{l}\text { Never walked } \\
\text { without support }\end{array}$ \\
\hline 10 & $\mathrm{R} 79 \mathrm{H}$ & $\mathrm{F}$ & 0.58 & Seizure & Mild ID & Walks without support & Ataxia & ND \\
\hline 11 & $\mathrm{R} 79 \mathrm{H}$ & $\mathrm{F}$ & 0.5 & Arching back and eye rolling upward & Normal & Walks with support & Seizures & $\begin{array}{l}\text { Yet to walk } \\
\text { without support }\end{array}$ \\
\hline 12 & $\mathrm{R} 79 \mathrm{H}$ & $\mathrm{F}$ & 1.25 & Seizure & Moderate ID & Walks without support & Motor skills, cognition & No \\
\hline 13 & $\mathrm{R} 79 \mathrm{H}$ & $\mathrm{F}$ & 0 & Hypotonia & Severe ID & Reaching for objects & $\mathrm{N} / \mathrm{A}$ & $\mathrm{N} / \mathrm{A}$ \\
\hline 14 & R79L & M & 0.5 & $\begin{array}{l}\text { Progressive macrocephaly; slowed } \\
\text { development }\end{array}$ & Moderate ID & $\begin{array}{l}\text { Walks a few steps } \\
\text { without support }\end{array}$ & None & No \\
\hline 15 & $\mathrm{R} 88 \mathrm{C}$ & M & 4 & $\begin{array}{l}\text { Short stature, followed by slowed } \\
\text { cognitive development }\end{array}$ & Mild ID & Walks without support & Progressive dysarthria, cognitive delay & No \\
\hline 16 & $\mathrm{R} 88 \mathrm{C}$ & M & 0.75 & Macrocephaly, developmental delay & Mild ID & Walks with support & None & $\begin{array}{l}\text { Yet to walk } \\
\text { without support }\end{array}$ \\
\hline 17 & $\mathrm{R} 88 \mathrm{C}$ & M & 2 & Seizure & Mild ID & Walks without support & Motor decline, seizures, bulbar problems & 5 years \\
\hline 18 & $\mathrm{R} 88 \mathrm{C}$ & M & 10 & Deterioration in academic skills & Mild ID & Walks without support & Neurocognitive decline and spasticity & No \\
\hline 19 & $\mathrm{R} 88 \mathrm{C} \dagger$ & $\mathrm{F}$ & 10 & Vomiting, anorexia & Normal & Walks without support & Scoliosis, gait & 30 years \\
\hline 20 & $\mathrm{R} 88 \mathrm{C} \dagger$ & M & 10 & Incoordination & Normal & Walks without support & Scoliosis, gait, some cognitive decline & No \\
\hline 21 & R105W $\ddagger$ & $\mathrm{F}$ & 6 & Memory, math and spelling, behavior & Mild ID & Walks without support & None & No \\
\hline 22 & L123P & M & 50 & Progressive gait problems, inbalance & Normal & Walks without support & Bulbar dysfunction & ND \\
\hline 23 & E207Q & M & 10.5 & $\begin{array}{l}\text { Scoliosis, followed by abnormal gait, } \\
\text { fatigue, and weakness }\end{array}$ & Normal & Walks without support & Difficulty walking, urinary incontinence & 22 years \\
\hline 24 & $\mathrm{~L} 231 \mathrm{H} \dagger$ & M & 50 & Ataxia & Normal & Walks without support & Ataxia & 63 years \\
\hline 25 & $\mathrm{~L} 231 \mathrm{H} \dagger$ & M & na & None & Normal & Walks without support & None & No \\
\hline 26 & $\mathrm{R} 239 \mathrm{C}$ & M & 0.5 & Macrocephaly, developmental delay & Severe ID & Standing with support & Swallowing, tone, hydrocephalus & $\begin{array}{l}\text { Yet to walk } \\
\text { without support }\end{array}$ \\
\hline 27 & $\mathrm{R} 239 \mathrm{C}$ & $\mathrm{F}$ & 1.5 & $\begin{array}{l}\text { Hypotonia, gross motor delay, } \\
\text { macrocephaly }\end{array}$ & Severe ID & Walks with support & Failure to thrive, emesis, but no regression & $\begin{array}{l}\text { Yet to walk } \\
\text { without support }\end{array}$ \\
\hline 28 & $\mathrm{R} 239 \mathrm{C}$ & $\mathrm{F}$ & 7 & Choking episodes & Mild ID & Walks without support & $\begin{array}{l}\text { Gait deterioration, dysarthria, urinary } \\
\text { incontinence }\end{array}$ & No \\
\hline 29 & $\mathrm{R} 239 \mathrm{C}$ & $\mathrm{F}$ & 1.67 & Intermittent ataxia & Normal & Walks without support & Occasional unsteadiness & No \\
\hline 30 & $\mathrm{R} 239 \mathrm{H}$ & $\mathrm{F}$ & 0.29 & $\begin{array}{l}\text { Vomiting, hypotonia, minimal } \\
\text { development }\end{array}$ & Only social contact & None at all & Progressive bulbar dysfunction & $\begin{array}{l}\text { Never walked } \\
\text { without support }\end{array}$ \\
\hline 31 & $\mathrm{R} 239 \mathrm{H}$ & $\mathrm{F}$ & 0 & Hydrocephalus, minimal development & Severe ID & None & $\mathrm{N} / \mathrm{A}$ & N/A \\
\hline 32 & R239P & M & 2 & Vomiting, deterioration of gait & Moderate ID & Walks without support & Mild deterioration of gait & No \\
\hline 33 & $\mathrm{R} 239 \mathrm{P}$ & M & 1.5 & Speech and motor delay & Mild ID & Walks with support & None & $\begin{array}{l}\text { Yet to walk } \\
\text { without support }\end{array}$ \\
\hline 34 & S247P & M & 10 & Severe morning emesis & Normal & Walks without support & Sleep apnea & No \\
\hline 35 & $\mathrm{R} 258 \mathrm{P}$ & M & 0 & Macrocephaly, hypotonia & Mild-moderate ID & Walks without support & Seizures, dysarthria, ataxia & No \\
\hline 36 & $\begin{array}{l}\text { R270- } \\
\text { A272del }\end{array}$ & $\mathrm{F}$ & $<0.25$ & Motor delay, macrocephaly & Severe ID & Very limited & $\mathrm{N} / \mathrm{A}$ & $\mathrm{N} / \mathrm{A}$ \\
\hline 37 & Q290E & $\mathrm{F}$ & 12 & Worsening migraines & Normal & Walks without support & No & No \\
\hline 38 & E362Q & $\mathrm{F}$ & 5 & Seizures, ataxia, rigidity & Normal & Normal & $\begin{array}{l}\text { Dysarthria, short-term memory, executive } \\
\text { function }\end{array}$ & No \\
\hline 39 & E371Q & M & $<1$ & Motor delay & Mild ID & Walks without support & Neurocognitive delay & No \\
\hline 40 & E373A & $\mathrm{F}$ & 34 & Numbness, burning sensation & Normal & Normal gait & Fatigue, balance, bladder & No \\
\hline 41 & E374G & $\mathrm{F}$ & 0 & Hypotonia, lack of development & Moderate ID & Walks with support & Lost all skills, frequent vomiting & $\begin{array}{l}\text { Never walked } \\
\text { without support }\end{array}$ \\
\hline 42 & $\mathrm{~S} 398 \mathrm{~F}$ & $\mathrm{~F}$ & 45 & Dysarthria & Normal & Walks without support & Ataxia, palatal tremor & No \\
\hline 43 & S398Y & $\mathrm{F}$ & $51 *$ & $\begin{array}{l}\text { MRI after subarachnoid hemorrhage at } \\
51 \text { years, mild urinary urgency } \\
\text { at } 56 \text { years }\end{array}$ & Normal & Walks without support & Urinary urge-incontinence, unsteadiness & No \\
\hline 44 & M415I† & $\mathrm{F}$ & 40 & Balance difficulties & Normal & Walks without support & Speech, urinary, headache & No \\
\hline 45 & $\begin{array}{l}\text { M415It, } \\
\text { D157N§ }\end{array}$ & $\mathrm{F}$ & 4 & Ataxia & Normal & Walks without support & Urinary retention, bulbar dysfunction & $\sim 8$ years \\
\hline 46 & $\mathrm{R} 416 \mathrm{~W}$ & M & 14 & $\begin{array}{l}\text { Behavior and gait problems; single } \\
\text { seizure }\end{array}$ & Low normal & Walks without support & Ataxia, dysarthria, behavior & 18 years \\
\hline 47 & R416W & M & 13 & Dysarthria, dysphagia & Normal & Walks without support & $\begin{array}{l}\text { Cognitive impairment, neurogenic bladder, } \\
\text { obstructive sleep apnea, palatal tremor }\end{array}$ & 29 years \\
\hline 48 & R416W & M & 6 & Febrile seizure & Low normal & Walks without support & Mild proximal weakness & No \\
\hline
\end{tabular}


Table 4: Continued

\begin{tabular}{|c|c|c|c|c|c|c|c|c|}
\hline $\begin{array}{l}\text { Patient } \\
\text { no. }\end{array}$ & Mutation & Sex & Onset & First symptom & Highest cognitive & Highest motor & Main deterioration & $\begin{array}{l}\text { Age at loss of } \\
\text { unassisted walking }\end{array}$ \\
\hline 49 & R416W & $\mathrm{F}$ & 16 & Balance, bladder & Normal & Walks without support & $\begin{array}{l}\text { Balance coordination, weakness, swallowing, } \\
\text { hallucinations }\end{array}$ & No \\
\hline 50 & Q426L & $\mathrm{F}$ & 30 & Urinary incontinence, neurogenic bladder & Normal & Normal & Exercise intolerance & 45 \\
\hline
\end{tabular}

Information regarding each patient is shown including age of onset, nature of first symptom, highest cognitive level, highest motor level, major deterioration (if any), and age at loss of unassisted walking (if it occurred). All ages are given in years. ID, Intellectual disability; N/A, not applicable; ND, not determined or unknown; F, female; M, male.

*Age of onset was estimated.

†Parent-child duos are shown together on consecutive lines (19-20, 24-25, and 44-45).

$\ddagger$ The pathogenicity of the R105 mutation is uncertain.

$\S$ The D157N mutation is considered a benign variant, but its impact in a compound heterozygote is not known.

blood values are significantly elevated only in the putative type I patients (type I patients vs control subjects, $p=$ $0.001^{\text {d }}$; type II patients vs control subjects, $p=0.203^{\mathrm{e}}$ ). Additional information about the statistical tests used throughout and the confidence intervals for each set of comparisons is given in Table $\mathbf{5}$.

\section{Discussion}

In an earlier study of three AxD patients, Kyllerman et al. (2005) found that GFAP levels in CSF were elevated compared with a previously analyzed reference range of control subjects. We here confirm the consistent elevation of GFAP levels in CSF samples in a larger cohort of patients, analyzed at the same time as control subjects. We further report that GFAP levels are also elevated above the control range in blood samples, but only in a subset of patients. Our results provide the necessary foundation for future studies aimed at developing appropriate biomarkers of disease severity, progression, and response to treatments.

Why GFAP levels in CSF (and occasionally blood) rise in AxD patients is not clear. Previous work in mouse models suggests a linear relation between the levels in parenchyma (presumably largely intracellular) and that in the fluids (Jany et al., 2013), and it is known that GFAP levels are elevated in brain lysates from AxD patients (Tang et al., 2008; Walker et al., 2014). That the infantile- and juvenile-onset groups display higher fluid levels than adult-onset patients may reflect underlying differences in their parenchymal levels, but such direct correlations remain to be established. The precise origin and form of extracellular GFAP are also not certain, but presumably result from either astrocyte death or sublethal injury that increases the permeability of the plasma membrane (Liem and Messing, 2009; Petzold, 2015). GFAP is not known to be secreted, as has been reported for vimentin from macrophages (Mor-Vaknin et al., 2003), though unpublished studies suggest that it might be exported via exo- somes (K. Glebov, personal communication). Recent studies of the newly discovered "glymphatic" pathway for solute flow in the brain suggest that GFAP may reach the blood through paravascular channels and olfactory pathways rather than a leaky blood-brain barrier (Plog et al., 2015). However, it is possible that glymphatic clearance itself, which is dependent on the astrocytic water channel AQP4, is also affected in AxD patients.

Individuals with $A x D$ experience several associated conditions that plausibly could influence GFAP expression and levels in biofluids. Seizures are seen in most infantile or type I AxD patients (Brenner et al., 2009; Prust et al., 2011), and kindling has been shown in rat models to transiently increase the expression of GFAP even in the contralateral hippocampus (Steward et al., 1991). Nevertheless, in our sample we found no obvious connection linking GFAP levels with the co-occurrence or degree of control of seizures. Conditions involving more obvious destruction of brain parenchyma, such as hydrocephalus (Tullberg et al., 1998; Beems et al., 2003; Petzold et al., 2004) or cavitating lesions (Rosengren et al., 1994), might also be expected to contribute to increased spillage of GFAP into the extracellular space, and subsequently into CSF and blood. Nevertheless, GFAP blood levels were elevated in only one of the five patients noted to have hydrocephalus. Whether certain features of MRI findings in individual AxD patients, such as cavitation or simple contrast enhancement (reflecting breakdown of the blood-brain barrier), predict changes in GFAP levels in CSF and blood is a topic for future study.

We recognize a number of limitations to our study. First is the problem of age matching in our samples, particularly with respect to blood. Our IRB protocol limited the collection of blood from healthy control subjects to those $>18$ years of age, whereas 27 of our 48 AxD patient samples were below this age. However, previous studies of GFAP in CSF and blood found no relation to age or sex

Table 5: Statistical table

\begin{tabular}{llll}
\hline & Data structure & Type of test & $95 \% \mathrm{Cl}$ \\
a & Quantitative scale, non-normally distributed & Wilcoxon rank sum test & $1876-14226 \mathrm{ng} / \mathrm{L}$ \\
b & Quantitative scale, non-normally distributed & Wilcoxon rank sum test & $191-1015 \mathrm{ng} / \mathrm{L}$ \\
c & Quantitative scale, non-normally distributed & Wilcoxon rank sum test & $40-563 \mathrm{ng} / \mathrm{L}$ \\
d & Quantitative scale, non-normally distributed & Wilcoxon rank sum test & $250-710 \mathrm{ng} / \mathrm{L}$ \\
e & Quantitative scale, non-normally distributed & Wilcoxon rank sum test & $-110-381 \mathrm{ng} / \mathrm{L}$ \\
\hline
\end{tabular}


(Petzold et al., 2004; Mayer et al., 2013), though with a small sample Rosengren et al. (1992) found that adult CSF values were slightly higher than those in children. Second, while the processing of the blood samples in our study was well defined and standardized, for CSF we could access only leftover clinical samples, which may have varied considerably with respect to the interval between collection and freezing. Our assays did not distinguish between full-length protein and forms that are truncated through degradation, but previous studies (Missler et al., 1999; Petzold et al., 2004) have shown that GFAP is stable for several days at $4^{\circ} \mathrm{C}$ and is not affected by multiple freeze-thaw cycles. In addition, circadian rhythms influence the production rate of CSF (Nilsson et al., 1992), and the levels of at least some biomarkers (e.g., amyloid $\beta$ ) are known to vary depending on the time of collection (Bateman et al., 2007). We note that the quantitation of proteins involved in aggregation disorders may be compromised by the "hook" effect, but the impact would be to underestimate the degree of elevation, particularly when assaying tissues where the aggregates typically reside (Lu et al., 2011; Petzold, 2015). Finally, we have examined only samples taken at one time point during the disease process; for many of the AxD patients who contributed CSF samples, they were taken at different times than the blood samples. Hence, our data cannot be used to establish direct connections between the values in blood and CSF, nor can we reach any conclusions about how GFAP levels might change in an individual during progression of disease.

Ultimately, a panel of biomarkers may prove more informative than focusing on just one. Several candidates for consideration in such a panel could include markers of neuronal or oligodendroglial injury (e.g., neuron-specific enolase, $\mathrm{UCH}-\mathrm{L} 1$, neurofilament-H, MBP). A recent proteomic study of CSF in one mouse model of AxD (Cunningham et al., 2013) suggested additional potential biomarkers that may be of interest, including cathepsins and creatine kinase $\mathrm{M}$.

\section{References}

Barreau P, Prust MJ, Crane J, Loewenstein J, Kadom N, Vanderver $A$ (2011) Focal central white matter lesions in Alexander disease. $J$ Child Neurol 26:1422-1424. CrossRef Medline

Bateman RJ, Wen G, Morris JC, Holtzman DM (2007) Fluctuations of CSF amyloid- $\beta$ levels: implications for a diagnostic and therapeutic biomarker. Neurology 68:666-669. CrossRef Medline

Beems T, Simons KS, van Geel WJA, de Reus HPM, Vos PE, Verbeek MM (2003) Serum- and CSF-concentrations of brain specific proteins in hydrocephalus. Acta Neurochir (Wien) 145:37-43. CrossRef Medline

Brenner M, Goldman JE, Quinlan RA, Messing A (2009) Alexander disease: a genetic disorder of astrocytes. In: Astrocytes in (Patho)physiology of the nervous system (Parpura V, Haydon PG, eds), pp 591-648. New York: Springer.

Brenner M, Johnson AB, Boespflug-Tanguy O, Rodriguez D, Goldman JE, Messing A (2001) Mutations in GFAP, encoding glial fibrillary acidic protein, are associated with Alexander disease. Nat Genet 27:117-120. CrossRef Medline

Caroli F, Biancheri R, Seri M, Rossi A, Pessagno A, Bugiani M, Corsolini F, Savasta S, Romano S, Antonelli C, Romano A, Pareyson D, Gambero P, Uziel G, Ravazzolo R, Ceccherini I, Filocamo M (2007) GFAP mutations and polymorphisms in 13 unrelated Italian patients affected by Alexander disease. Clin Genet 72:427-433. CrossRef Medline

Cho W, Brenner M, Peters N, Messing A (2010) Drug screening to identify suppressors of GFAP expression. Hum Mol Genet 19: 3169-3178. CrossRef Medline

Cunningham R, Jany P, Messing A, Li L (2013) Protein changes in immunodepleted cerebrospinal fluid from a transgenic mouse model of Alexander disease detected using mass spectrometry. $J$ Proteome Res 12:719-728. CrossRef Medline

de Souza Rezende SA, Fernandes M, Munhoz RP, Raskin S, Schelp AO, van der Knaap MS, Teive HAG (2012) Cerebellar ataxia as the first manifestation of Alexander's disease. Arq Neuropsiquiatr 70: 309-310. Medline

Delnooz CCS, Schelhaas JH, van de Warrenburg BP, de Graaf RJ, Salomons GS (2008) Alexander disease causing hereditary lateonset ataxia with only minimal white matter changes: a report of two sibs. Mov Disord 23:1613-1615. CrossRef Medline

Farina L, Pareyson D, Minati L, Ceccherini I, Chiapparini L, Romano S, Gambaro P, Fancellu R, Savoiardo M (2008) Can MR imaging diagnose adult-onset Alexander disease? Am J Neuroradiol 29: 1190-1196. CrossRef Medline

Gorospe JR, Naidu S, Johnson AB, Puri V, Raymond GV, Jenkins SD, Pedersen RC, Lewis D, Knowles P, Fernandez R, De Vivo D, van der Knaap MS, Messing A, Brenner M, Hoffman EP (2002) Molecular findings in symptomatic and pre-symptomatic Alexander disease patients. Neurology 58:1494-1500. Medline

Hagemann TL, Connor JX, Messing A (2006) Alexander diseaseassociated glial fibrillary acidic protein mutations in mice induce Rosenthal fiber formation and a white matter stress response. $J$ Neurosci 26:11162-11173. CrossRef

Hagemann TL, Gaeta SA, Smith MA, Johnson DA, Johnson JA, Messing A (2005) Gene expression analysis in mice with elevated glial fibrillary acidic protein and Rosenthal fibers reveals a stress response followed by glial activation and neuronal dysfunction. Hum Mol Genet 14:2443-2458. CrossRef Medline

Iwaki T, Iwaki A, Tateishi J, Sakaki Y, Goldman JE (1993) Alpha B-crystallin and 27-kd heat shock protein are regulated by stress conditions in the central nervous system and accumulate in Rosenthal fibers. Am J Pathol 143:487-495. Medline

Iwaki T, Kume-Iwaki A, Liem RKH, Goldman JE (1989) Alpha B-crystallin is expressed in non-lenticular tissues and accumulates in Alexander's disease brain. Cell 57:71-78. Medline

Jany PL, Hagemann TL, Messing A (2013) GFAP expression as an indicator of disease severity in mouse models of Alexander disease. ASN Neuro 5:e00109.doi:10.1042/AN20130003. CrossRef Medline

Johnson AB, Bettica A (1989) On-grid immunogold labeling of glial intermediate filaments in epoxy-embedded tissue. Am J Anat 185: 335-341. CrossRef Medline

Kyllerman M, Rosengren L, Wiklund LM, Holmberg E (2005) Increased levels of GFAP in the cerebrospinal fluid in three subtypes of genetically confirmed Alexander disease. Neuropediatrics 36: 319-323. CrossRef Medline

Li R, Johnson AB, Salomons G, Goldman JE, Naidu S, Quinlan R, Cree B, Ruyle SZ, Banwell B, D'Hooghe M, Siebert JR, Rolf CM, Cox H, Reddy A, Gutiérrez-Solana LG, Collins A, Weller RO, Messing A, van der Knaap MS, Brenner M (2005) Glial fibrillary acidic protein mutations in infantile, juvenile, and adult forms of Alexander disease. Ann Neurol 57:310-326. CrossRef Medline

Liem RKH, Messing A (2009) Dysfunctions of neuronal and glial intermediate filaments in disease. J Clin Invest 119:1814-1824. CrossRef Medline

Lu CH, Kalmar B, Malaspina A, Greensmith L, Petzold A (2011) A method to solubilise protein aggregates for immunoassay quantification which overcomes the neurofilament "hook" effect. J Neurosci Methods 195:143-50. CrossRef Medline

Matarese CA, Renaud DL (2008) Magnetic resonance imaging findings in Alexander disease. Pediatr Neurol 38:373-374. CrossRef Medline 
Mayer CA, Brunkhorst R, Niessner M, Pfeilschifter W, Steinmetz H, Foerch C (2013) Blood levels of glial fibrillary acidic protein (GFAP) in patients with neurological diseases. PLoS ONE 8:e62101. CrossRef Medline

Messing A, Goldman JE (2004) Alexander disease. In: Myelin biology and disorders, Vol 2 (Lazzarini RA, eds), pp 851-866. Amsterdam: Elsevier. [CrossRef][10.1042/AN20130003]

Messing A, Head MW, Galles K, Galbreath EJ, Goldman JE, Brenner M (1998) Fatal encephalopathy with astrocyte inclusions in GFAP transgenic mice. Am J Pathol 152:391-398. Medline

Messing A, Daniels CM, Hagemann TL (2010) Strategies for treatment in Alexander disease. Neurotherapeutics 7:507-15. CrossRef Medline

Messing A, Li R, Naidu S, Taylor JP, Silverman L, Flint D, van der Knaap MS, Brenner M (2012a) Archetypal and new families with Alexander disease and novel mutations in GFAP. Arch Neurol 69:208-214. CrossRef Medline

Messing A, Brenner M, Feany MB, Nedergaard M, Goldman JE (2012b) Alexander disease. J Neurosci 32:5017-5023. CrossRef Medline

Missler U, Wiesmann M, Wittmann G, Magerkurth O, Hagenström H (1999) Measurement of glial fibrillary acidic protein in human blood: analytical method and preliminary clinical results. Clin Chem 45:138-141. Medline

Mor-Vaknin N, Punturieri A, Sitwala K, Markovitz DM (2003) Vimentin is secreted by activated macrophages. Nat Cell Biol 5:59-63. CrossRef Medline

Nilsson C, Stahlberg F, Thomsen C, Henriksen O, Herning M, Owman C (1992) Circadian variation in human cerebrospinal fluid production measured by magnetic resonance imaging. Am J Physiol Regul Integr Comp Physiol 262:R20-R24.

Pareyson D, Fancellu R, Mariotti C, Romano S, Salmaggi A, Carella F, Girotti F, Gattellaro G, Carriero MR, Farina L, Ceccherini I, Savoiardo M (2008) Adult-onset Alexander disease: a series of eleven unrelated cases with review of the literature. Brain 131: 2321-2331. CrossRef Medline

Petzold A (2015) Glial fibrillary acidic protein is a body fluid biomarker for glial pathology in human disease. Brain Res 1600:17-31. CrossRef Medline

Petzold A, Keir G, Green AJE, Giovannoni G, Thompson EJ (2004) An ELISA for glial fibrillary acidic protein. J Immunol Methods 287: 169-177. CrossRef Medline

Plog BA, Dashnaw ML, Hitomi E, Peng W, Liao Y, Lou N, Deane R, Nedergaard M (2015) Biomarkers of traumatic injury are transported from brain to blood via the glymphatic system. J Neurosci 35:518-26. CrossRef Medline

Prust M, Wang J, Morizono H, Messing A, Brenner M, Gordon E, Hartka T, Sokohl A, Schiffmann R, Gordish-Dressman H, Albin R, Amartino H, Brockman K, Dinopoulos A, Dotti MT, Fain D, Fernandez R, Ferreira J, Fleming J, Gill D, et al (2011) GFAP mutations, age at onset, and clinical subtypes in Alexander disease. Neurology 77:1287-1294. CrossRef Medline

Richardson DB, Ciampi A (2003) Effects of exposure measurement error when an exposure variable is constrained by a lower limit. Am J Epidemiol 157:355-63. Medline
Rosengren LE, Ahlsén G, Belfrage M, Gillberg C, Haglid KG, Hamberger A (1992) A sensitive ELISA for glial fibrillary acidic protein: application in CSF of children. J Neurosci Methods 44:113-119. Medline

Rosengren LE, Wikkelsø C, Hagberg L (1994) A sensitive ELISA for glial fibrillary acidic protein: Application in CSF of adults. J Neurosci Methods 51:197-204. Medline

Russo LS Jr, Aron A, Anderson PJ (1976) Alexander's disease: a report and reappraisal. Neurology 26:607-614. Medline

Steward O, Torre ER, Tomasulo R, Lothman E (1991) Neuronal activity up-regulates astroglial gene expression. Proc Natl Acad Sci U S A 88:6819-6823. Medline

Tanaka KF, Takebayashi H, Yamazaki Y, Ono K, Naruse M, Iwasato T, Itohara S, Kato H, Ikenaka K (2007) Murine model of Alexander disease: analysis of GFAP aggregate formation and its pathological significance. Glia 55:617-631. CrossRef Medline

Tang G, Yue Z, Talloczy Z, Hagemann T, Cho W, Messing A, Sulzer DL, Goldman JE (2008) Autophagy induced by Alexander diseasemutant GFAP accumulation is regulated by p38/MAPK and mTOR signaling pathways. Hum Mol Genet 17:1540-1555. CrossRef Medline

Tian RJ, Gregor M, Wiche G, Goldman JE (2006) Plectin regulates the organization of glial fibrillary acidic protein in Alexander disease. Am J Pathol 168:888-897. CrossRef Medline

Tullberg M, Rosengren L, Blomsterwall E, Karlsson JE, Wikkelsö C (1998) CSF Neurofilament and glial fibrillary acidic protein in normal pressure hydrocephalus. Neurology 50:1122-1127. Medline

van der Knaap MS, Naidu S, Breiter SN, Blaser S, Stroink H, Springer S, Begeer JC, Van Coster R, Barth PG, Thomas NH, Valk J, Powers JM (2001) Alexander disease: diagnosis with MR imaging. Am J Neuroradiol 22:541-552. Medline

van der Knaap MS, Ramesh V, Schiffmann R, Blaser S, Kyllerman M, Gholkar A, Ellison DW, van der Voorn JP, van Dooren SJM, Jakobs C, Barkhof F, Salomons GS (2006) Alexander disease: ventricular garlands and abnormalities of the medulla and spinal cord. Neurology 66:494-498. CrossRef Medline

van der Knaap MS, Salomons GS, Li R, Franzoni E, González Gutiérrez-Solana L, Smit LME, Robinson R, Ferrie C, Cree B, Reddy A, Thomas N, Banwell B, Barkhof F, Jakobs C, Johnson A, Messing A, Brenner M (2005) Unusual variants of Alexander disease. Ann Neurol 57:327-338. CrossRef Medline

Walker AK, LaPash Daniels CM, Goldman JE, Trojanowski JQ, Lee VM-Y, Messing A (2014) Astrocytic TDP-43 pathology in Alexander disease. J Neurosci 34:6448-6458. CrossRef Medline

Yoshida T, Sasaki M, Yoshida M, Namekawa M, Okamoto Y, Tsujino S, Sasayama H, Mizuta I, Nakagawa M (2011) Nationwide survey of Alexander disease in Japan and proposed new guidelines for diagnosis. J Neurol 258:1998-2008. CrossRef Medline

Yue JK, Vassar MJ, Lingsma HF, Cooper SR, Okonkwo DO, Valadka AB, Gordon WA, Maas AIR, Mukherjee P, Yuh EL, Puccio AM, Schnyer DM, Manley GT, Casey SS, Cheong M, Dams-O'Connor K, Hricik AJ, Knight EE, Kulubya ES, Menon DK, et al (2013) Transforming research and clinical knowledge in traumatic brain injury pilot: multicenter implementation of the common data elements for traumatic brain injury. J Neurotrauma 30:1831-1844. CrossRef 